\title{
Article/Artigo
}

\section{Prevalence of Trypanosoma cruzi antibodies and inflammatory markers in uncompensated heart failure}

\author{
Prevalência de anticorpos anti-Trypanosoma cruzi e marcadores inflamatórios em pacientes \\ com insuficiência cardíaca descompensada
}

\author{
Iván Bravo Tobar ${ }^{1}$, Freddy Parra ${ }^{3}$, Carlota Nello Pérez ${ }^{1}$, Claudina Rodríguez-Bonfante ${ }^{2}$, Franco Useche \\ and Rafael Bonfante-Cabarcas ${ }^{1}$
}

\begin{abstract}
Introduction: Heart failure (HF) represents the final stage of chronic chagasic cardiomyopathy $(\mathrm{CChC})$. The diagnosis of $\mathrm{CChC}$ is based on the demonstration of anti-Trypanosoma cruzi antibodies (aTcAg) and clinical and epidemiological data. In Venezuela, there are no data about the prevalence of chagasic HF. The aim of this study was to determine the epidemiological, clinical, and inflammatory risk factors associated with seronegative or seropositive HF patients. Methods: We performed a cross-sectional study in the Venezuelan central-west states among a healthy rural population and in patients admitted to the emergency room with uncompensated HF. Results: The seroprevalence rates of Trypanosoma cruzi antibodies were $11.2 \%$ and $40.1 \%$ in the healthy population and in HF patients, respectively. Seropositivity in healthy individuals was associated with age, knowledge on triatomine vectors, and having seen wild reservoirs in the house; in HF patients, with contact with the vector and previous clinical diagnosis of Chagas' disease; and in both groups taken together, with age, knowledge on triatomines, and HF. Seropositive patients had prolonged QRS, decreased ejection fraction, and high serum magnesium, all significant as compared with HF seronegative cases. Left atrium enlargement and ventricular hypertrophy were most frequently observed in HF seronegative patients. CRP, IL6, IL $\beta 1$, IL2, and FNT $\alpha$ were elevated in $94.5 \%, 48 \%, 17.8 \%, 13.7 \%$, and $6.9 \%$ of HF patients, respectively, but only IL2 levels were associated with chagasic HF. Conclusions: There is a high prevalence of aTcAg in HF patients from the central-west region of Venezuela, and their epidemiological, clinical, and inflammatory features are discreetly different as compared with those of seronegative cases.
\end{abstract}

Keywords: Chagas disease. Heart failure. Seroprevalence. Cytokines. Magnesium.

\section{RESUMO}

Introdução: A insuficiência cardíaca (IC) representa o estágio final da cardiopatia chagásica crônica (CChC). O diagnóstico de CChC é baseado na demonstração de anticorpos antiTrypanosoma cruzi (AgTc), dados clínicos e epidemiológicos. Na Venezuela, não há informação sobre a prevalência da IC chagásica. $\mathrm{O}$ objetivo deste estudo foi determinar fatores de risco epidemiológicos, clínicos e inflamatórios associados à IC chagásica. Métodos: Realizamos um estudo prospectivo transversal em estados do centro-oeste da Venezuela em uma população rural saudável e em pacientes com IC descompensada. Resultados: A soroprevalência de AgTc mostrou valores de $11,2 \%$ e 40,1\% na população saudável e em pacientes com IC, respectivamente. A soropositividade de indivíduos sadios se associou com a idade, conhecimento de vetores e a observação de reservatórios silvestres na habitação. Em pacientes com IC, estavam relacionados ao contato com o vetor e ao diagnóstico clínico prévio de doença de Chagas. Em ambos os grupos juntos, a soropositividade foi associada com idade, conhecimento do vetor e com IC Os pacientes soropositivos apresentavam prolongamento do intervalo QRS, fração de ejeção diminuída e magnésio sérico elevado. Aumento atrial esquerdo e hipertrofia ventricular foram as mais frequentemente observadas em pacientes com IC soronegativos. PCR, IL6, IL $\beta 1$, IL2 e FNT $\alpha$ foram elevados em 94,5, 48, 17,8, 13,7 e em 6,9\% dos pacientes com IC, respectivamente; os níveis de IL-2 foram associados com IC chagásica. Conclusões: Uma alta prevalência de AgTc foi observada em pacientes com IC na região centro-oeste da Venezuela, cujos aspectos epidemiológicos, clínicos e inflamatórios são discretamente diferentes dos soronegativos.

Palavras-chaves: Doença de Chagas. Insuficiência cardíaca. Soroprevalência. Citocinas. Magnésio.

1. Unidade de Bioquímica, Decanato de Ciencias de la Salud, Universidade Centro-Occidental “Lisandro Alvarado” Barquisimeto, Estado Lara, Venezuela. 2. Unidade de Investigacões em Parasitología Médica, Decanato de Ciencias de la Salud, Universidade Centro-Occidental "Lisandro Alvarado" Barquisimeto, Estado Lara, Venezuela. 3. Emergencia General, Hospital Central “Antonio María Pineda”, Barquisimeto, Estado Lara, Venezuela.

Address to: Dr. Rafael Bonfante Cabarcas. Unidade Bioquímica/Decanato Medicina/UCLA. Av. Libertador con Andrés Bello s/n, 3001 Barquisimeto, Estado Lara, Venezuela.

Phone: 58251 259-1854; Fax: $58251259-1950$

e-mail: rcabarca@ucla.edu.ve

Received in 23/09/2010

Accepted in 28/07/2010

\section{INTRODUCTION}

Chagas disease is a zoonosis caused by the hemoprotozoan Trypanosoma cruzi, transmitted to hosts by hematophagous Reduviidae vectors of the Triatominae subfamily. The disease is endemic in 18 countries in the Americas, with 28 million people at risk of infection and 15 million infected people. It is estimated that there are 41,200 new cases each year, with an overall mortality of 12,500 people $^{1}$.

In Venezuela, there has been a progressive decline in prevalence rates over the past forty years, from $44.5 \%$ in the period from $1950-1960$ to $8.3 \%$ in $2000^{2}$. This outcome is the result of the implementation of various actions, including house replacement, vector control, blood screening, and prevention programs in vulnerable areas. These measures have reduced the annual incidence of 10 per 1,000 inhabitants in 1950 to 1 per 1,000 inhabitants in $1980^{3}$.

Chronic chagasic cardiomyopathy (CChC) is a particular type of inflammatory chronic myocarditis that occurs decades after the onset of infection and produces heart lesions characterized by cardiomyocyte hypertrophy, T-cell mononuclear infiltrates, fibrosis, and abnormalities of the microcirculation, which together hold a progression to cardiac dysfunction and the development of arrhythmias, heart failure, and sudden death ${ }^{4}$.

In Latin America, CChC is considered one of the leading causes of $\mathrm{HF}^{5}$, and the prevalence of anti-Trypanosoma cruzi antibodies in patients with HF have been broadly studied in Brazil, reporting values from 20 to $48 \%^{5-9}$. Heart failure is a final stage of CChC.

When it is a consequence of an infectious or chronic disease, HF is considered as a chronic inflammatory process having a strong immune activation in which a large variety of proinflammatory cytokines are involved in its development, for example, tumor necrosis factor (TNF), interleukin 6 (IL6), Interleukin-1 $\beta$ (IL1 $\beta$ ), and interleukin-2 (IL2) ${ }^{10}$.

In Chagas disease, inflammation plays a central role in progression towards $\mathrm{CChC}$. Indirectly 
activated inflammatory cells trigger the synthesis of acute-phase reactant factors, such as $\mathrm{C}$-reactive protein (CRP) and the cytokine IL6; these factors are sensitive markers of myocardial damage induced by Trypanosoma cruzi $i^{11}$. Recently, our group demonstrated that serum levels of CRP, TNF- $\alpha$, and IL6 increase as Chagas disease evolves into a serious illness and that patients with heart failure have the highest levels ${ }^{11-12}$.

In order to determine epidemiological, clinical, and inflammatory risk factors associated with chagasic HF, we performed a crosssectional study in a healthy rural population and in patients admitted to the emergency room at the general hospitals of the Venezuelan central-west states.

\section{METHODS}

We conducted a cross-sectional study that included healthy individuals who voluntarily attended rural health clinics in the State of Lara for Chagas disease screening and HF patients admitted to the emergency room at the main hospitals in the central-west region of Venezuela (states of Lara and Portuguesa), specifically in the cities of Barquisimeto, Carora, and Acarigua, which are the reference health centers in this region in Venezuela. Rural health clinics were randomly selected in each of the 8 municipalities of the state of Lara.

The sample consisted of 1,210 healthy individuals and 162 patients with HF. Healthy people were interviewed to fill out an epidemiological record, and each patient with heart failure underwent a detailed clinical evaluation that included clinical and epidemiological history, physical examination, 12-lead electrocardiogram at rest, chest radiology, conventional M-mode echocardiogram, complete blood cell count, hemoglobin and haematocrit tests, and fasting blood chemistry, including glucose, sodium, potassium, calcium, magnesium, creatinine, urea, uric acid, and alanine and aspartate transaminases.

The clinical diagnosis of HF was done according to Framingham criteria and grouped in functional class III or IV according to the New York Heart Association (NYHA) classification.

Patients were classified according to etiology in: a) ischemic heart disease - a documented clinic history or electrocardiographic signs of coronary heart disease (including ischemia, lesion, or myocardial infarction), an abnormal stress test or pathological coronary angiography, angina pectoris, and increased levels of myocardial enzymes; b) hypertensive heart disease - patients with a documented history of treated hypertension, current or former electrocardiographic signs of hypertrophy and/or left ventricular overload, and systolic blood pressure greater than $130 \mathrm{mmHg}$ and diastolic blood pressure greater than $90 \mathrm{mmHg}$ on admission, c) valvular heart disease - patients with a documented history and diagnosis of congenital or communicating valvular heart disease, rheumatic fever or non-rheumatic valvular disease, presence of grade III/IV murmurs during physical examination, and electrocardiographic, radiological, and/or ultrasound signs suggesting valvular disease; d) mixed heart disease - patients with a diagnosis of at least two of the three above-mentioned heart diseases; e) dilated idiopathic cardiomyopathy - patients with no documented clinical history, no electrocardiographic, echocardiographic, radiologic, or laboratory data related to ischemic heart disease, no hypertensive heart disease or valvular heart disease, nor other causes that give rise to congestive, such as renal failure, diabetes mellitus, metabolic syndrome, anemia, and myocardial toxicity by drugs or substances of abuse, among others.

Excluded were all individuals or patients with HF due to acute coronary disease, myocardial toxicity, kidney failure, anemia, or chronic obstructive pulmonary disease, as well as autoimmune diseases, systemic infectious diseases, or generalized malignancy.

\section{Determination of anti-Trypanosoma cruzi antibodies}

The serological diagnosis of Chagas disease was based on the determination of anti-Trypanosoma cruzi IgG antibodies through three (3) serological tests: direct agglutination, indirect immunofluorescence, and ELISA. Individuals were considered seropositive when at least two of the tests were reactive.

\section{Determination of cytokine levels and C-reactive protein}

In 73 (28 seropositive and 45 seronegative) patients from Barquisimeto's central hospital, the serum levels of proinflammatory cytokines (IL1 $\beta$, IL2, IL6, TNF- $\alpha$ ) were assayed using commercial kits $\left(\right.$ Diaclone $\left.{ }^{\circledast}\right)$, based on a double-sandwich enzyme immunoassay (ELISA), according to the manufacturer's specifications (http://www.gen-probe.com/global/product-search/productsearch.asp?). C-reactive protein levels were determined using an immunoturbidimetry method. Tumor necrosis factor- $\alpha$ has an analytical sensitivity of $<10 \mathrm{pg} / \mathrm{mL}$, the intra- and inter-assay variations are less than 12 and $15 \%$, respectively, and the reference value is $\leq 12 \mathrm{pg} /$ $\mathrm{mL}$. Interleukin- 6 has an analytical sensitivity of $\leq 2 \mathrm{pg} / \mathrm{mL}$, the intraand inter-assay variations are less than 4 and $8 \%$, respectively, and the reference value is $\leq 5 \mathrm{pg} / \mathrm{ml}$. Interleukin- 2 has an analytical sensitivity of $<10 \mathrm{pg} / \mathrm{ml}$, the intra- and inter-assay variations are less than 9 and $10 \%$, respectively, and the reference value is $\leq 10 \mathrm{pg} / \mathrm{mL}$. Interleukin$1 \beta$ has an analytical sensitivity of $\leq 5 \mathrm{pg} / \mathrm{mL}$, the intra- and inter-assay variations are less than 8 and $11 \%$, respectively, and the reference value is $\leq 5 \mathrm{pg} / \mathrm{ml}$. C-reactive protein has an analytical sensitivity of $<0.6 \mathrm{mg} / \mathrm{L}$, the intra- and inter-assay variations are less than 5 and $11 \%$, respectively, and the reference value for this study is $<1 \mathrm{mg} / \mathrm{L}$.

\section{Statistical analysis}

The data are expressed as absolute values, percentages, or the mean \pm standard error. Binary logistic regression analyses were used to evaluate the adjusted association between more than one independent variable and a continuous dependent variable, specifically the association between clinical or epidemiologic data and seropositivity. Student's t-test was used to compare averages, and the Chi-square and the Fisher exact tests were used on proportions. In all cases, significance was accepted at $\mathrm{p}<0.05$. The software GraphPad Prism 4.0 (GraphPad Software, La Jolla, CA, USA) and SPSS 11.0.1 were used for statistical analysis.

\section{Ethical considerations}

The study protocol was approved by the Ethics Committee at the School of Health Sciences, "Lisandro Alvarado" University, Barquisimeto, State of Lara, Venezuela, in accordance with the Helsinki Declaration of 1964, as revised in 1975, 1983, 1989, 1996, and 2000. Data were collected after the participants signed the informed consent.

\section{RESULTS}

\section{Healthy population}

Of the 1,210 individuals, $754(62.3 \%)$ were female and $456(37.7 \%)$ were male; 135 (11.2\%) were seropositive: 89 (66\%) females and $46(34.1 \%)$ males, obtaining prevalence rates of $11.8 \%$ and $11.2 \%$, 
respectively. The arithmetic average of the ages of the seropositive individuals was $21.98 \pm 43.87$ (standard deviation) years (percentile $25 \%=25$, percentile $75 \%=63$ years, median $=45$ years). The arithmetic average of the ages of the seronegative individuals was $18.9 \pm \mathrm{SD}$ 24.75 years $(25 \%$ percentile $=10$ years, $75 \%$ percentile $=36$ years, median $=21$ years). The seropositivity of healthy individuals was associated with age (odds ratio (OR): 1.04; 95\% confidence interval (CI): 1.03-1.05, $\mathrm{p}=0.00$ ), knowledge on triatomines (OR: $0.35,95 \%$ CI: 0.17-0.69, $\mathrm{p}=0.003)$, and recalling having seen wild reservoirs get in the house (OR: 2.27, 95\% CI: 1.05-4 9, p=0.04).

\section{Heart failure patients}

Of all the studied individuals $(\mathrm{n}=162), 65$ were seropositive, which represents a prevalence of $40.1 \%$. The arithmetic average age of seropositive individuals was $69.40 \pm 12.73$ years, ranging from $22-95$ years, with an average age of 70 . The arithmetic average of the ages of the seronegative individuals was $66.51 \pm 15.57$ years, ranging from $20-95$ years, with a mean age of 68 years. The logistic regression analysis of the clinical and epidemiological characteristics of HF patients with regard to serology showed an association between exposure to the vector (OR: $2.17,95 \%$ CI: $0.99-4.17, \mathrm{p}=0.05$ ) and previous clinical diagnosis of Chagas disease (OR: 5.36, 95\% CI: 1.65-17.47, p=0.005), both in relation to the presence of serum antibodies against Trypanosoma cruzi.

By analyzing both groups of patients as a single population, we found that HF was associated with age (OR: 1,103, 95\% CI: 1,088-1,119, p: 0.00) and male sex (OR: 1.86, 95\% CI: 1.20-2.87, $\mathrm{p}=0.005$ ), while seropositivity was associated with age (OR: 1,037, 95\% CI: 1,027-1,046, $\mathrm{p}=0.00)$, knowledge on triatomines
(OR: $3.26,95 \%$ CI: $1.65-6.45, \mathrm{p}=0.001$ ), and HF (OR: 3.28 , 95\% CI: $1.45-7.41, \mathrm{p}=0.004)$.

\section{Clinical, electrocardiographic, and echocardiographic characteristics}

Hypertensive heart disease was the most frequently observed, mainly in seronegative individuals. Dilated and chronic ischemic heart disease occurred more frequently in seropositive individuals; however, no association was found between HF clinical etiology and seropositivity (Table 1).

In the analysis of electrocardiogram (EKG) traces, we found that PR and QRS segments did not present a significant difference between the serological groups (PR: seronegative $0.183 \pm$ SD 0.05 sec, seropositive $0.17 \pm S D$ 0.06, $p>0.05$; $Q R S$ : seropositive $0.10 \pm S D$ 0.029 , seronegative $0.093 \pm$ SD $0.028, p>0.05$ ). The most frequently observed arrhythmia was atrial fibrillation in $36.6 \%$ and $33.7 \%$ of seropositive and seronegative patients, respectively, without any statistical significance $(p>0.05)$. The conduction disturbance more frequently observed in both groups was a His left bundle branch block, while left atrium enlargement and left ventricular hypertrophy were observed more frequently in the seronegative patients (Table 2).

The ventricular ejection fraction was decreased in the studied patients, but it was significantly higher in the NYHA class III patients $(44.8 \pm 2.6 \%)$ as compared with the NYHA class IV patients $(36.6 \pm 1.4 \%$; $<<0.05)$, as well as in the seronegative patients $(41 \pm 1.7 \%)$ as compared with the seropositive patients $(34.9 \pm 1.3 \%$; $\mathrm{p}<0.05$ ) (Table 3).

The clinical and biochemical parameters tested in this work are presented in Table 3. In relation to this point, we observed that 8.8 and $45.6 \%$ of the patients showed levels of glicemia below 70 and above $110 \mathrm{mg} / \mathrm{dL}$, respectively; however, no differences in absolute or percentage values were observed when comparing seropositive against seronegative patients and NYHA class III against NYHA class IV cases. Also, serum magnesium levels were significantly elevated in seropositive as compared with seronegative patients, and in NYHA class III versus NYHA class IV patients. Likewise, serum sodium levels were significantly decreased in seropositive as compared with antibodies.

\begin{tabular}{|c|c|c|c|c|c|c|c|c|c|c|}
\hline & \multicolumn{5}{|c|}{ Seronegative } & \multicolumn{5}{|c|}{ Seropositive } \\
\hline & \multicolumn{2}{|c|}{ female } & \multicolumn{2}{|c|}{ male } & \multirow{2}{*}{$\begin{array}{c}\text { total } \\
\mathbf{n}\end{array}$} & \multicolumn{2}{|c|}{ female } & \multicolumn{2}{|c|}{ male } & \multirow{2}{*}{$\begin{array}{r}\text { total } \\
n\end{array}$} \\
\hline & $\mathbf{n}$ & $\%$ & $\mathbf{n}$ & $\%$ & & $\mathbf{n}$ & $\overline{\%}$ & $\mathbf{n}$ & $\%$ & \\
\hline Dilated & 8 & 66.6 & 4 & 33.4 & 12 & 6 & 46.2 & 7 & 53.8 & 13 \\
\hline Hypertensive & 19 & 48.7 & 20 & 51.3 & 39 & 14 & 60.9 & 9 & 39.1 & 23 \\
\hline Ischemic & 5 & 41.6 & 7 & 58.4 & 12 & 4 & 30.8 & 9 & 69.2 & 13 \\
\hline Mixed & 11 & 34.4 & 21 & 65.6 & 32 & 12 & 75.0 & 4 & 25.0 & 16 \\
\hline Valvular & 1 & 50.0 & 1 & 50.0 & 2 & 0 & 0 & 0 & 0.0 & 0.0 \\
\hline Total & 44 & - & 53 & - & 97 & 36 & - & 29 & - & 65 \\
\hline
\end{tabular}

TABLE 3 - Clinical and biochemical parameters in patients with heart failure.

\begin{tabular}{lccccc}
\hline \multirow{2}{*}{ Parameter } & positive & negative & & III & IV \\
\cline { 2 - 3 } \cline { 6 - 6 } Heart rate & $104.50 \pm 5.90$ & $101.80 \pm 4.66$ & & $103.90 \pm 5.35$ & $102.20 \pm 4.89$ \\
\hline SBP & $112.20 \pm 5.97$ & $123.00 \pm 3.53$ & & $120.60 \pm 3.83$ & $117.70 \pm 4.55$ \\
\hline DBP & $71.36 \pm 2.67$ & $74.49 \pm 3.01$ & & $72.92 \pm 2.85$ & $72.93 \pm 2.25$ \\
\hline CTI & $0.66 \pm 0.01$ & $0.66 \pm 0.01$ & & $0.67 \pm 0.01$ & $0.66 \pm 0.01$ \\
\hline Hemoglobin & $11.54 \pm 0.36$ & $11.87 \pm 0.34$ & & $12.36 \pm 0.45$ & $11.42 \pm 0.29$ \\
\hline Glucose & $123.90 \pm 14.75$ & $111.20 \pm 8.94$ & & $109.60 \pm 9.52$ & $118.70 \pm 10.50$ \\
\hline Creatinin & $1.34 \pm 0.14$ & $1.45 \pm 0.12$ & & $1.51 \pm 0.14$ & $1.38 \pm 0.12$ \\
\hline Calcium & $9.19 \pm 0.15$ & $9.05 \pm 0.14$ & & $9.08 \pm 0.23$ & $9.12 \pm 0.10$ \\
\hline Magnesium & $2.35 \pm 0.10^{* *}$ & $2.08 \pm 0.07$ & & $2.33 \pm 0.13^{* *}$ & $2.10 \pm 0.05$ \\
\hline Sodium & $131.80 \pm 1.39^{* *}$ & $135.30 \pm 0.84$ & & $133.10 \pm 1.67$ & $134.40 \pm 0.80$ \\
\hline Potassium & $4.62 \pm 0.43$ & $4.55 \pm 0.21$ & & $4.74 \pm 0.52$ & $4.50 \pm 0.19$ \\
\hline NYHA & & & & & \\
\cline { 5 - 6 }
\end{tabular}

NYHA: New York Heart Association; SBP: systolic blood pressure; DBP: diastolic blood pressure; CTI: cardiothoracic index. ${ }^{*}$ stage of heart failure according to the NYHA; ${ }^{* *}$ means $\mathrm{p}<0.05$ when positive and negative or III or IV are compared. in patients with heart failure.

\begin{tabular}{|c|c|c|c|c|c|c|c|c|}
\hline \multirow[b]{3}{*}{ Disturbance } & \multicolumn{4}{|c|}{ Seropositive } & \multicolumn{4}{|c|}{ Seronegative } \\
\hline & \multicolumn{2}{|c|}{ present } & \multicolumn{2}{|c|}{ absent } & \multicolumn{2}{|c|}{ present } & \multicolumn{2}{|c|}{ absent } \\
\hline & $\mathbf{n}$ & $\%$ & $\mathbf{n}$ & $\%$ & $\mathbf{n}$ & $\%$ & $\mathbf{n}$ & $\%$ \\
\hline $\mathrm{AF}$ & 24 & 36.9 & 41 & 63.1 & 33 & 34.0 & 64 & 66.0 \\
\hline AVB & 8 & 12.3 & 57 & 87.7 & 17 & 17.5 & 80 & 82.5 \\
\hline $\mathrm{LBB}^{\circ}$ & 29 & 44.6 & 36 & 55.4 & 40 & 41.2 & 57 & 58.8 \\
\hline RBB & 13 & 20.0 & 52 & 80.0 & 12 & 12.4 & 85 & 87.6 \\
\hline LAE & 5 & 7.7 & 60 & 92.3 & $18^{*}$ & 18.6 & 79 & 81.4 \\
\hline$\overline{\mathrm{RAE}}$ & 2 & 3.1 & 63 & 96.9 & 6 & 6.2 & 91 & 93.8 \\
\hline LVH & 7 & 10.8 & 58 & 89.2 & $26^{*}$ & 26.8 & 71 & 73.2 \\
\hline
\end{tabular}

AF: atrial fibrilation; AVB: atrioventricular block; LBB: left bundle block; RBB: right bundle block; LAE: left atrial enlargement; RAE: right atrial enlargement; LVH: left ventricular hypertrophy. ${ }^{*}$ means $\mathrm{p}<0.05$ when seropositive vs seronegative patients or the conduction disturbances are compared, respectively, through a contingency table using Chi-square test. 
seronegative patients, but no differences were observed when NYHA class III were compared with NYHA class IV patients.

\section{Cytokines and $\mathrm{C}$-reactive protein}

Interleukin-6 and CRP were elevated in a large proportion of the patients. Being more sensitive, CRP was elevated in $94.5 \%$ of the patients, whereas IL6 was elevated in $48 \%$ of the cases (Tables 4 and 5 ).

FNT $\alpha$, IL $\beta 1$, and IL2 were elevated in a low proportion of patients, with frequencies of $6.9 \%, 17.8 \%$, and $13.7 \%$, respectively. Elevated levels of IL2 were associated with seropositive patients but not with HF severity. Elevated levels of IL $\beta 1$ and FNT $\alpha$ were associated with neither HF severity nor the presence of antibodies against Trypanosoma cruzi (Tables 4 and $\mathbf{5}$ ).

By analyzing the absolute values of the CRP, we observed that serum levels of this protein were significantly $(\mathrm{p}=0.0003)$ lower in NYHA class III patients $(1.61 \pm 0.20 \mathrm{pg} / \mathrm{mL})$ as compared to NYHA class IV patients $(5.01 \pm 0.63 \mathrm{pg} / \mathrm{mL}, \mathrm{p}<0.05)$; however, the serum levels were similar for seropositive $(3.16 \pm 0.61)$ and seronegative patients $(4.14 \pm 0.62 \mathrm{pg} / \mathrm{mL} ; \mathrm{p}=0.279)$. For $\mathrm{TNF} \alpha, \mathrm{IL} 1 \beta$, and IL2, we failed to observe any significant differences in serum absolute levels in relation to HF severity or serology.

TABLE 4 - Frequency of elevated levels of cytokines and C-reactive protein in relation to NYHA functional class of the heart failure.

\begin{tabular}{|c|c|c|c|c|c|c|}
\hline & \multicolumn{2}{|c|}{ III } & \multicolumn{2}{|c|}{ IV } & \multicolumn{2}{|c|}{ Total } \\
\hline & $\mathbf{n}$ & $\%$ & $\mathbf{n}$ & $\%$ & $\mathbf{n}$ & $\%$ \\
\hline TNF $\alpha$ & 1 & 4.0 & 4 & 8.3 & 5 & 6.9 \\
\hline $\mathrm{IL} 1 \beta$ & 7 & 28.0 & 6 & 12.5 & 13 & 17.8 \\
\hline IL2 & 4 & 16.0 & 6 & 12.5 & 10 & 13.7 \\
\hline IL6 & 14 & 56.0 & 21 & 43.8 & 35 & 48.0 \\
\hline CRP & 22 & 88.0 & 47 & 97.9 & 69 & 94.5 \\
\hline
\end{tabular}

NYHA: New York Heart Association; TNFa: tumoral necrosis factor $\alpha$; IL1 $\beta$ : Interleukin-1 beta; IL2: interleukin-2; IL6: interleukin-6; CRP: C-reactive protein. Reference values for this study: $\mathrm{TNF} \alpha \leq 12 \mathrm{pg} / \mathrm{ml}, \mathrm{IL} 1 \beta \leq 5 \mathrm{pg} / \mathrm{ml}, \mathrm{IL} 2 \leq 10 \mathrm{pg} / \mathrm{ml}$, IL $6 \leq 2 \mathrm{pg} / \mathrm{ml}$, and $\mathrm{CRP}<1 \mathrm{mg} / \mathrm{L}$.

TABLE 5 - Frequency of elevated levels of cytokines and C-reactive protein in relation to the presence of anti-Trypanosoma cruzi antibodies in patients with heart failure.

\begin{tabular}{|c|c|c|c|c|c|c|}
\hline & \multicolumn{2}{|c|}{ Seronegative } & \multicolumn{2}{|c|}{ Seropositive } & \multicolumn{2}{|c|}{ Total } \\
\hline & $\mathbf{n}$ & $\%$ & $\mathbf{n}$ & $\%$ & $\mathbf{n}$ & $\%$ \\
\hline $\mathrm{TNF} \alpha$ & 3 & 6.7 & 2 & 7.1 & 5 & 6.9 \\
\hline $\mathrm{IL} 1 \beta$ & 10 & 22.2 & 3 & 10.7 & 13 & 17.8 \\
\hline IL2 & 3 & 6.7 & $7^{*}$ & 25.0 & 10 & 13.7 \\
\hline IL6 & 21 & 46.7 & 14 & 50.0 & 35 & 48.0 \\
\hline CRP & 43 & 95.6 & 26 & 92.9 & 69 & 94.5 \\
\hline
\end{tabular}

TNFa: tumoral necrosis factor $\alpha$, IL1 $\beta$ : Interleukin-1 beta, IL2: interleukin-2, IL6: interleukin-6; CRP: C-reactive protein. Reference values for this study: $\mathrm{TNF} \alpha \leq 12 \mathrm{pg} / \mathrm{ml}, \mathrm{IL} 1 \beta \leq 5 \mathrm{pg} / \mathrm{ml}, \mathrm{IL} 2 \leq 10 \mathrm{pg} / \mathrm{ml}, \mathrm{IL} 6 \leq 2 \mathrm{pg} / \mathrm{ml}$, and $\mathrm{CRP}<1 \mathrm{mg} / \mathrm{L}$.

\section{DISCUSSION}

The main objective of this study was to establish risk factors associated with congestive heart failure and to establish differences in clinical features and inflammatory responses between seronegative and seropositive HF patients.

The $11.2 \%$ seroprevalence reported in this work for apparently healthy populations is similar to that reported in a multidisciplinary, multicenter study conducted during 1988 to 2003 in 11 states of Venezuela. The authors of the said study obtained an $11.2 \%$ prevalence rate in the general population, with an $8.5 \%$ age-specific prevalence in infants less than 10 years; in the present study, we obtained $2.23 \%$ prevalence in the same age range. These two studies are comparable from the methodological point of view since both are based on accidental sampling strategies and used the same diagnostic tools ${ }^{13}$.

In this paper, we present results that define a $40.1 \%$ seroprevalence of anti-Trypanosoma cruzi antibodies in HF patients in the centralwest region of Venezuela. To our knowledge, this is the first seroepidemiological study on the prevalence of anti-Trypanosoma cruzi antibodies in Venezuelan uncompensated HF patients.

In Latin America, several studies have been conducted to determine the seroprevalence of anti-Trypanosoma cruzi antibodies in patients with dilated cardiomyopathy with or without HF. In Mexico, the reported seroprevalence rates have ranged from 19.4\% in Yucatán to $82.5 \%$ in Chiapas ${ }^{14-15}$; in Brazil, the prevalence has been reported to range from $20 \%$ in São Paulo to $48 \%$ in Bahia ${ }^{5-9}$. All authors agree that seroprevalence is higher in HF patients; however, the point of interest is to ascertain whether the HF syndrome in seropositive patients is a consequence of $\mathrm{CChC}$.

In this sense, Higuchi et al. ${ }^{16}$ found a higher incidence of active myocarditis in seropositive patients with heart failure. Bellotti et al. ${ }^{17}$ and Benvenutti et al. ${ }^{18}$ also showed a significant correlation between the presence of Trypanosoma cruzi antigens and the presence of a moderate or severe myocarditis. Additionally, Schijman et al. ${ }^{19}$ reported a positive correlation between mononuclear cell infiltration, fibrosis grade, and clinical HF evolution, and the detection of Trypanosoma cruzi by PCR. All these studies were performed on endomyocardial biopsies taken from patients with Chagas disease, which could suggest that Trypanosoma cruzi is associated with the development of chronic CChC, and seropositive status should be considered a risk factor for HF development.

Patients with Chagas disease have a worse prognosis than patients with $\mathrm{HF}$ resulting from other etiologies ${ }^{5,8,20}$. This poor prognosis has been associated with the presence of ventricular tachycardia, low ejection fraction, bradycardia, decreased systolic pressure, decreased $\mathrm{VO}_{2}$ max, activation of the renin-angiotensin system, and elevated levels of cytokines $^{7-8}$.

Chronic chagasic cardiomyopathy has a specific pathophysiology that distinguishes it from other etiologies; it has predominance in males and in ages between 30 and 60 years, and is characterized by right bundle branch block associated with left anterior hemiblock, ventricular and atrial arrhythmias, bradyarrhythmias, biventricular dysfunction, left ventricular apical aneurysm, thromboembolic events, and sudden death ${ }^{8}$. Notwithstanding, in this study we observed left bundle branch block and atrial fibrillation more frequently, both in seronegative and seropositive patients, without any statistically association between serology status and type of disturbance. Moreover, we observed no association between valvular, hypertensive, idiopathic dilated, or ischemic cardiomyopathies and the serological status of the patient. These results create a controversy regarding the real etiology of HF in our patients, indicating that the presence of Trypanosoma cruzi antibodies in heart failure patients does not really signify a chagasic etiology.

However, left bundle branch block has been reported with high frequency in patients with Chagas disease, especially in asymptomatic cases $^{21-22}$; likewise, in patients with chagasic heart disease, the frequency of right bundle branch block is similar to that previously 
reported ${ }^{23}$. On the other hand, in Venezuela no difference between seropositive and seronegative patients has been reported in terms of the prevalence of chronic heart disease in adults from rural communities, suggesting the existence of a rural endemic chronic heart disease in this country ${ }^{24}$. Similarly, other studies performed in asymptomatic patients showed no statistically significant clinical, electrocardiographic, or radiological differences between seropositive and seronegative patients ${ }^{22}$. All these studies suggest a common pathophysiological mechanism that could have been triggered by a myocardial insult from different causes.

These pathological insults could trigger neurohormonal and inflammation phenomena that sustain the pathogenic evolution to HF. The cytokine hypothesis for HF suggests that HF progresses because the cytokines released after a myocardial injury exert a deleterious effect on the heart and induce the release of acute-phase proteins $s^{25}$.

In this regard, we find that an unspecific marker of systemic inflammation, CRP, and the cytokine IL6 were elevated in 94.5 and $48 \%$ of HF patients, respectively, without any association with seroreactivity. Likewise, CRP levels were significantly elevated in NYHA class IV patients with a significantly lower ventricular ejection fraction, suggesting that CRP could be a marker of HF severity.

C-reactive protein has been associated with acute coronary syndromes and patient evolution after acute myocardial infarction. A large number of studies have shown the predictive value of serum CRP, relating it to future atherothrombotic events, including coronary events, stroke, and progression of peripheral vascular disease. Similarly, CRP has been shown to be elevated in HF patients, and it has a prognostic value as an independent mortality and morbidity predictor ${ }^{26}$.

Interleukin-6 is a key inflammatory factor; its secretion activates CRP release, and it has been implicated in the pathogenesis and clinical course of cardiovascular diseases. Elevated circulating levels of IL6 have been demonstrated in HF patients, and their serum level expression in cardiac tissue has been correlated with severity of left ventricular function and progression of $\mathrm{HF}^{27}$. IL6 has a negative inotropic effect as a consequence of an IL6-induced myocardium hypocontractile state, which explains why patients with uncompensated HF have higher IL6 levels than patients in the recovery phase ${ }^{28}$, reflecting the hemodynamic deterioration in HF patients $^{29}$. In the present paper, even though IL6 levels were elevated in $48 \%$ of patients, they were not associated with seropositivity or with higher degrees of HF.

Lopez et al. ${ }^{11}$ demonstrated an association between the clinical stage of Chagas disease and the levels of IL6, which in turn was associated with a higher rate of left ventricular mass and with the male sex; elevated CRP levels were only associated with more advanced stage of Chagas disease. In the present study, serum CRP levels were statistically higher in NYHA class IV as compared with NYHA class III patients; however, we did not observe any significant differences in serum CRP levels between seropositive and seronegative HF patients, confirming that CRP levels are associated with HF functional severity and not with HF etiology.

Tumor necrosis factor- $\alpha$ levels are elevated in patients with HF, and the magnitude of the increase has been directly correlated with severity of the disease. The increased levels of TNFa is a consequence of the production by the failing heart and by the inflammatory cells due to Trypanosoma cruzi infection in chagasic patients, causing fibrosis and apoptosis, and inducing negative inotropic effects with systolic dysfunction ${ }^{30}$. In the present study, we observed elevated levels of this cytokine only in $6.9 \%$ of patients; this result is similar to that reported by van Riemsdijk-van Overbeeke et al. ${ }^{31}$, who failed to detect serum levels of free TNF $\alpha$ in HF patients notwithstanding their finding of elevated levels of TNF $\alpha$ soluble receptors with increased binding capacity, which explained the low TNFa bioavailability. Additionally, no change in the levels of this cytokine when compared to control healthy individuals was reported in two other studies done in patients with mild or moderate heart failure ${ }^{32-33}$.

Interleukin-2 levels were observed in 25 and $6.7 \%$ of seropositive and seronegative patients, respectively, being statistically associated with seropositivity. Of the 7 seropositive patients with elevated IL2, 6 were in NYHA class IV, suggesting that IL2 is a marker of CChC severity. Interleukin-2 levels have been associated with HF caused by idiopathic dilated cardiomyopathy, where the levels of IL2 and its soluble receptor are predictors of a more severe clinical course ${ }^{34}$. Interleukin-2 induces activation and proliferation of $\mathrm{T}$ cells, which are involved in myocardial inflammatory infiltration in idiopathic dilated cardiomyopathy ${ }^{35}$. On the other hand, this cytokine is not elevated in patients with HF etiologically associated with ischemic or hypertensive heart disease ${ }^{35}$, which agrees with the observations done in the present paper.

Increased levels of IL $1 \beta$ were observed in $17.8 \%$ of patients analyzed in the present work and were not associated with serologic or functional status. In relation to IL $1 \beta$ and cardiovascular disease, Testa et al. ${ }^{36}$ reported that 25 to $37 \%$ of HF patients due to coronary heart disease and/or hypertension, ranging from NYHA class III to NYHA class IV, displayed higher levels of IL1 $\beta$, which was correlated with severity of the disease. Similarly, Peraza-Cruces et al. ${ }^{37}$ showed that IL $1 \beta$ levels were elevated in the plasma of rats with chronic Chagas disease and in an in vitro Chagas disease model conditioned medium.

In this study, serum magnesium levels were significantly higher in seropositive and NYHA class III patients when compared with seronegative and NYHA class IV patients, respectively. Hypomagnesemia has been associated with HF, premature ventricular contractions, and ventricular tachycardia; in HF patients, it has been associated with increased mortality ${ }^{38}$.

Finally, we found that the plasma level of sodium was significantly lower in seropositive as compared with seronegative patients. Hyponatraemia has been shown to be an independent predictor of mortality in patients with heart failure ${ }^{39}$.

In conclusion, our study presents data suggesting a high prevalence of CChC in patients with HF in the central-west region of Venezuela. The clinical features and levels of inflammatory markers discreetly differentiate seropositive and seronegative HF patients, with the most important distinguishing aspects being QRS prolongation, elevated serum levels of magnesium, and elevated IL2 serum levels in seropositive patients. Enlargement of the right atrium and left ventricular hypertrophy are associated with seronegative patients.

\section{ACKNOWLEDGMENTS}

The authors are deeply grateful to Drs. Darkis Díaz, Maria Dos Santos, Nadia Oré, Elsa Valles, Ludwig Peñaranda, Ivanesa Pardo, Teresa D’Agostino, and Alejandra Garcia, who actively collaborated in collecting data for this paper. 


\section{CONFLICT OF INTEREST}

The authors declare that there is no conflict of interest.

\section{FINANCIAL SUPPORT}

Ministerio del Poder Popular para la Ciencia y Tecnología, Misión Ciencia, Fondo Nacional de Ciencia y Tecnología (Fonacit) Proyecto $N^{\circ}$ 2007001425; and Proyecto Integral de Chagas registrado en Consejo de Desarrollo Científico, Humanístico y Tecnológico (CDCHT) de la Universidad Centroccidental Lisandro Alvarado (UCLA).

\section{REFERENCES}

1. Dias JCP, Prata A, Correia D. Problems and perspectives for Chagas disease control: in search of a realistic analysis. Rev Soc Bras Med Trop 2008; 41:193-196.

2. Aché A, Matos AJ. Interrupting Chagas' disease transmisión in Venezuela. Rev Inst Med Trop São Paulo 2001; 43:37-43.

3. Feliciangeli D, Campbell-Lendrum D, Martínez C, González D, Coleman P, Davies C. Chagas disease control in Venezuela: lessons for the Andean region and beyond. Trends Parasitol 2003; 19:44-49.

4. Rassi Jr A, Rassi A, Marin-Neto JA. Chagas heart disease: pathophysiologic mechanisms, prognostic factors and risk stratification. Mem Inst Oswaldo Cruz 2009; 104 (suppl 1):152-158.

5. Freitas HF, Chizzola PR, Paes AT, Lima AC, Mansur AJ. Risk stratification in a Brazilian hospital-based cohort of 1220 outpatients with heart failure: role of Chagas' heart disease. Int J Cardiol 2005; 102:239-247.

6. Lopes CBC, Yamada AT, Araújo F, Pereira Barreto AC, Mansur AJ. Socioeconomic factors in the prognosis of heart failure in a Brazilian cohort. Int J Cardiol 2006; 113:181-187.

7. Rassi S, Barretto ACP, Porto CC, Pereira CR, Calaça BW, Rassi DC. Sobrevida e fatores prognósticos na insuficiência cardíaca sistólica com início recente dos sintomas. Arq Bras Cardiol 2005; 84:309-313.

8. Silva CP, Del Carlo CH, Oliveira Jr MT, Scipioni A, Strunz-Cassaro C, Ramirez JA, et al. Why do patients with chagasic cardiomyopathy have worse outcomes than those with non-chagasic cardiomyopathy? Arq Bras Cardiol 2008; 91:358-362.

9. Braga JC, Reis F, Aras R, Costa ND, Bastos C, Silva R, et al. Clinical and therapeutics aspects of heart failure due to Chagas disease. Arq Bras Cardiol 2006; 86:297-302.

10. Deswal A, Petersen NJ, Feldman AM, Young JB, White BG, Mann DL. Cytokines and cytokine receptors in advanced heart failure: an analysis of the cytokine database from the Vesnarinone trial (VEST). Circulation 2001; 103:2055-2059.

11. López L, Arai K, Giménez E, Jiménez M, Pascuzo C, Rodríguez-Bonfante C, et al. C-reactive protein and interleukin-6 serum levels increases as Chagas disease progresses towards cardiac failure. Rev Esp Cardiol 2006; 59:50-56.

12. D’Angelo-Mendoza E, Rodríguez-Bonfante C, Camacho I, Martínez J, Perdomo T, Cabrera A, et al. Patients suffering dilated chagasic cardiopathy or non chagasic cardiopathy show an increased levels of tumor necrosis factor alpha. Invest Clin $2005 ; 46: 229-240$

13. Añez N, Crisante G, Rojas A, Diaz N, Añez-Rojas N, Carrasco H, et al. La cara oculta de la enfermedad de Chagas de Venezuela. Bol Dir Mal San Amb 2003; 43:45-57.

14. Capps L, Abad B. Chagas cardiomyopathy and serologic testing in a small rural hospital in Chiapas, Mexico. Rev Panam Salud Publica 2004; 15:337-340.

15. Guillén-Ortega F, Pérez-Vargas A, Estrada-Suárez A, Moleres-Villegas J, Ricárdez-Esquinca J, Monteón Padilla V, et al. Antibodies against T. cruzi in patients with dilated cardiomyopathy in Tuxtla Gutierrez, Chiapas. Arch Cardiol Mex 2005; 75 (suppl 3):49-54.

16. Higuchi ML, Morais CF, Barreto ACP, Lopes EA, Stolf N, Bellotti G, et al. The role of active myocarditis in the development of heart failure in chronic Chagas' disease: a study based on endomyocardial biopsies. Clin Cardiol 1987; 10:665-670.

17. Bellotti G, Bocchi EA, Moraes AV, Higuchi ML, Barbero-Marcial M, Sosa E, et al. In vivo detection of Trypanosoma cruzi antigens in hearts of patients with chronic Chagas' heart disease. Am Heart J 1996; 131:301-307.

18. Benvenuti LA, Roggério A, Freitas HF, Mansur AJ, Fiorelli A, Higuchi ML. Chronic American trypanosomiasis: parasite persistence in endomyocardial biopsies is associated with high-grade myocarditis. Ann Trop Med Parasitol 2008; 102:481-487.

19. Schijman AG, Vigliano CA, Viotti RJ, Burgos JM, Brandariz S, Lococo BE, et al Trypanosoma cruzi DNA in cardiac lesions of Argentinean patients with end-stage chronic chagas heart disease. Am J Trop Med Hyg 2004; 70:210-220.

20. Nunes MCP, Barbosa MM, Ribeiro AL, Fenelon LMA, Rocha MO. Predictors of mortality in patients with dilated cardiomyopathy: relevance of chagas disease as an etiological factor. Rev Esp Cardiol 2010; 63:788-797.

21. Bar ME, Poseer DL, Alvarez BM, Vallejos JA, Storino RA. Estudio transversal clínico y epidemiológico de la enfermedad de Chagas en un área rural del Nordeste Argentino. Rev Soc Bras Med Trop 1998; 31:199-206.

22. Rigou A, Gullone N, Rosa A. Chagas asintomático. Hallazgos electrocardiográficos y ecocardiográficos. Medicina (Bs Aires) 2001; 61:541-544.

23. Acquatella H, Catalioti F, ManceboJG, Dávalos V, Villalobos L. Lon-term control of Chagas disease in Venezuela: effects on serologic findings, electrocardiographic abnormalities and clinical outcome. Circulation 1987; 75:556-562.

24. Novoa-Montero D. Cardiopatía crónica endémica rural chagásica o crónica común en chagásicos y no chagásicos? Rev Soc Ven Microbiol 2002; 22:1-20.

25. Seta Y, Shan K, Bozkurt B, Oral H, Mann DL. Basic mechanisms in heart failure: the cytokine hypothesis. J Card Fail 1996; 2:243-249

26. Villacorta H, Masetto AC, Mesquita ET. C-reactive protein: an inflammatory marker with prognostic value in patients with decompensated heart failure. Arq Bras Cardiol 2007; 88:585-589.

27. Kanda T, Takahashi T. Interleukin-6 and cardiovascular diseases. Jpn Heart J 2004; 45:183-193.

28. Sato Y, Takatsu Y, Kataoka K, Yamada T, Taniguchi R, Sasayama S, et al. Serial circulating concentrations of C-reactive protein, interleukin (IL)-4, and IL-6 in patients with acute left heart decompensation. Clin Cardiol 1999; 22:811-813.

29. Petretta M, Condorelli GL, Spinelli L, Scopacasa F, Caterina M, Leosco D, et al. Circulating levels of cytokines and their site of production in patients with mild to severe chronic heart failure. Am Heart J 2000; 140:E28.

30. Chung ES, Packer M, Lo KH, Fasanmade AA, Willerson JT. Anti-TNF Therapy Against Congestive Heart Failure Investigators. Randomized, double-blind, placebo-controlled, pilot trial of infliximab, a chimeric monoclonal antibody to tumor necrosis factor-alpha, in patients with moderate-to-severe heart failure: results of the anti-TNF Therapy Against Congestive Heart Failure (ATTACH) trial. Circulation 2003; 107:3133-3140.

31. van Riemsdijk-van Overbeeke IC, Baan CC, Niesters HG, Hesse CJ, Loonen EH, Balk AH, et al. The TNF-alpha system in heart failure and after heart transplantation: plasma protein levels, mRNA expression, soluble receptors and plasma buffer capacity. Eur Heart J 1999; 20:833-840.

32. Prichett G, Cohen HJ, Rao KM, Cobb F, Sullivan M, Currie MS. Tumor necrosis factor, natural killer activity and other measures of immune function and inflammation in elderly men with heart failure. Gerontology 1995; 41:45-56.

33. Munger MA, Johnson B, Amber IJ, Callahan KS, Gilbert EM. Circulating concentrations of proinflammatory cytokines in mild or moderate heart failure secondary to ischemic or idiopathic dilated cardiomyopathy. Am J Cardiol 1996; 77:723-727.

34. Limas CJ, Golderberg IF, Limas C. Soluble interleukin-2 receptor levels in patients with dilated cardiomyopathy: correlation with disease severity and cardiac autoantibodies. Circulation 1995; 91:631-634.

35. Holzinger C, Schollhammer A, ImhofM, Reinwald C, Kramer G, Zuckermann A, et al Phenotypic patterns of mononuclear cells in dilated cardiomyopathy. Circulation $1995 ; 92: 2876-2885$

36. Testa M, Yeh M, Lee P, Fanelli R, Loperfido F, Berman JW, et al. Circulating levels of cytokines and their endogenous modulators in patients with mild to severe congestive heart failure due to coronary artery disease or hypertension. J Am Coll Cardiol 1996; 28:964-971.

37. Peraza-Cruces K, Gutiérrez-Guédez L, Castañeda Perozo D, Lankford CR, Rodríguez-Bonfante C, Bonfante-Cabarcas R. Trypanosoma cruzi infection induces up-regulation of cardiac muscarinic acetylcholine receptors in vivo and in vitro. Braz J Med Biol Res 2008; 41:796-803.

38. Adamopoulos C, Pitt B, Sui X, Love TE, Zannad F, Ahmed A. Low serum magnesium and cardiovascular mortality in chronic heart failure: a propensitymatched study. Int J Cardiol 2009; 136:270-277.

39. Gheorghiade M, Abraham WT, Albert NM, Gattis Stough W, Greenberg BH, O'Connor CM, et al. OPTIMIZE-HF Investigators and Coordinators. Relationship between admission serum sodium concentration and clinical outcomes in patients hospitalized for heart failure: an analysis from the OPTIMIZE-HF registry. Eur Heart J 2007; 28:980-988. 